\title{
EVALUASI KEBUTUHAN RUANG PARKIR DI KAMPUS UNIVERSITAS BRAWIJAYA
}

\author{
Evaluation of Needs A Parking Space On The Campus Brawijaya University \\ Nuzul Wahyunita R², Harnen Sulistio ${ }^{2}$, Agus Suharyanto ${ }^{3}$ \\ 1,2,3 Jurusan Teknik Sipil, Fakultas TeknikUniversitas Brawijaya \\ Jln. MT. Haryono, Malang, Jatim \\ e-mail: nuzul_wr@yahoo.com
}

\begin{abstract}
An increasing number of students, faculty and staff that occurred at UB will produce a number of traffic movements are quite large due to use of each vehicle to campus, so that the number of vehicles entering volume resulting difficulty in obtaining adequate parking. Therefore this study aims to find out what the existing parking capacity at UB Campus, knowing what the parking needs at the present time, how the model predictions parking needs for the purpose of parking for 5 years to come, and make recommendations to the parking arrangement of five years to come. Models obtained from multiple linear regression analysis are: $Y 1=132.437+0.068 X 20,780 R^{2}$ value, and $Y 2=17.149+0249 X 30,952 R^{2}$ value. The capacity of the existing car park at the Campus $U B$ at this time in the amount of 624 SRP, while the capacity of the motorcycle that is equal to 5.312 SRP, and the need for car parking space at the moment at UB in the amount of 693 SRP, and to the needs of motorcycle parking space that is equal to 5.902 SRP. In order to meet the parking needs for the coming 5 years is the provision of alternative parking deck in 5 regions, with a total overall SRP for motorcycle with an area of 1.405 SRP of 2.107,5 $\mathrm{m}^{2}$ and parking for four-wheeled vehicles by 35 $S R P$ with a land area of $437,5 \mathrm{~m}^{2}$ parking
\end{abstract}

Keywords : Parking capacity, SRP, Regression Analysis, Parking Building

\begin{abstract}
Abstrak
Peningkatan jumlah mahasiswa, dosen dan karyawan yang terjadi di UB akan menghasilkan jumlah pergerakan lalu lintas yang besar karena menggunakan kendaraan pribadi menuju kampus, sehingga mengakibatkan kesulitan mendapatkan tempat parkir. Oleh karena itu penelitian ini bertujuan untuk mengetahui berapakah kapasitas parkir, berapakah kebutuhan parkir pada saat sekarang , bagaimanakah model kebutuhan parkir untuk keperluan prediksi parkir untuk 5 tahun yang akan datang, membuat rekomendasi penataan parkir pada 5 tahun yang akan datang. Model yang didapatkan dari analisa regresi linier berganda adalah $: Y_{1}=\mathbf{1 3 2 , 4 3 7}+\mathbf{0 . 0 6 8} \mathbf{X}_{2}$ memiliki nilai $R^{2} 0.780$ dan $Y_{2}=\mathbf{1 7 , 1 4 9}$ + 0.249 $\mathrm{X}_{3}$ memiliki nilai $\mathrm{R}^{2}$ 0.952 Kapasitas parkir mobil yaitu 624 SRP, sedangkan kapasitas sepeda motor yaitu 5.312 SRP. Kebutuhan ruang parkir mobil yaitu 693 SRP, dan kebutuhan ruang parkir sepeda motor yaitu 5.902 SRP. Guna memenuhi kebutuhan parkir untuk 5 tahun yang akan datang adalah dengan penyediaan alternatif gedung parkir di 5 kawasan, dengan total SRP keseluruhan untuk sepeda motor 1.405 SRP dengan luas parkir $2.107,5 \mathrm{~m}^{2}$ dan untuk mobil sebesar 35 SRP dengan luas parkir sebesar $437,5 \mathrm{~m}^{2}$
\end{abstract}

Kata Kunci: Kapasitas Parkir, SRP, Analisa Regresi, Gedung Parkir

\section{PENDAHULUAN}

Universitas Brawijaya merupakan salah satu pusat kegiatan pendidikan yang banyak diminati di Jawa Timur yaitu di tepatnya berada di Kota Malang. Pada saat ini Universitas Brawijaya memiliki 13 Fakultas yaitu Fakultas Hukum, Fakultas Ekonomi, Fakultas Ilmu Administrasi, Fakultas Pertanian, Fakultas Peternakan, Fakultas Teknik, Fakultas
Kedokteran, Fakultas Perikanan dan Ilmu Kelautan, Fakultas MIPA, Fakultas Teknologi Pertanian, Fakultas Ilmu Sosial dan Ilmu Politik, Fakultas Teknologi Informasi dan Ilmu Komputer, Program Kedokteran Hewan, dan Program Vokasi.

Interaksi yang terjadi di antara mahasiswa, pegawai dan dosen pada Universitas Brawijaya Malang memerlukan perjalanan yang akan menghasilkan jumlah pergerakan lalu lintas yang 
cukup besar. Hal ini akan sangat berpotensi menimbulkan kemacetan arus lalu lintas, baik dalam Kampus Universitas (pada jaringan jalan di luar Kampus Universitas Brawijaya Malang). Untuk mengantisipasi permasalahan tersebut, penyediaan sarana dan prasarana pengendalian arus lalu lintas barupa sistem sirkulasi arus dan sistem perparkirannya mutlak diperlukan. Dalam konteks tersebut hal pertama yang penting dilakukan adalah mengetahui dan mengestimasi besarnya pergerakan yang masuk dan keluar dari Kampus Universitas Brawijaya Malang sehingga nantinya dapat juga dilakukan forecasting untuk mengantisipasi permasalahan yang akan terjadi dimasa yang akan datang.

Adapun tujuan dari penelitian ini adalah:
- Mengetahui kapasitas parkir yang ada di Kampus Universitas Brawijaya, Malang

- Mengetahui kebutuhan parkir pada saat sekarang

- Membuat model kebutuhan parkir untuk keperluan prediksi parkir untuk 5 tahun yang akan datang

- Membuat rekomendasi penataan parkir pada 5 tahun yang akan datang.

\section{METODE PENELITIAN}

Metode penelitian adalah suatu kerangka pendekatan pola pikir dalam rangka menyusun dan melaksanakan suatu penelitian.

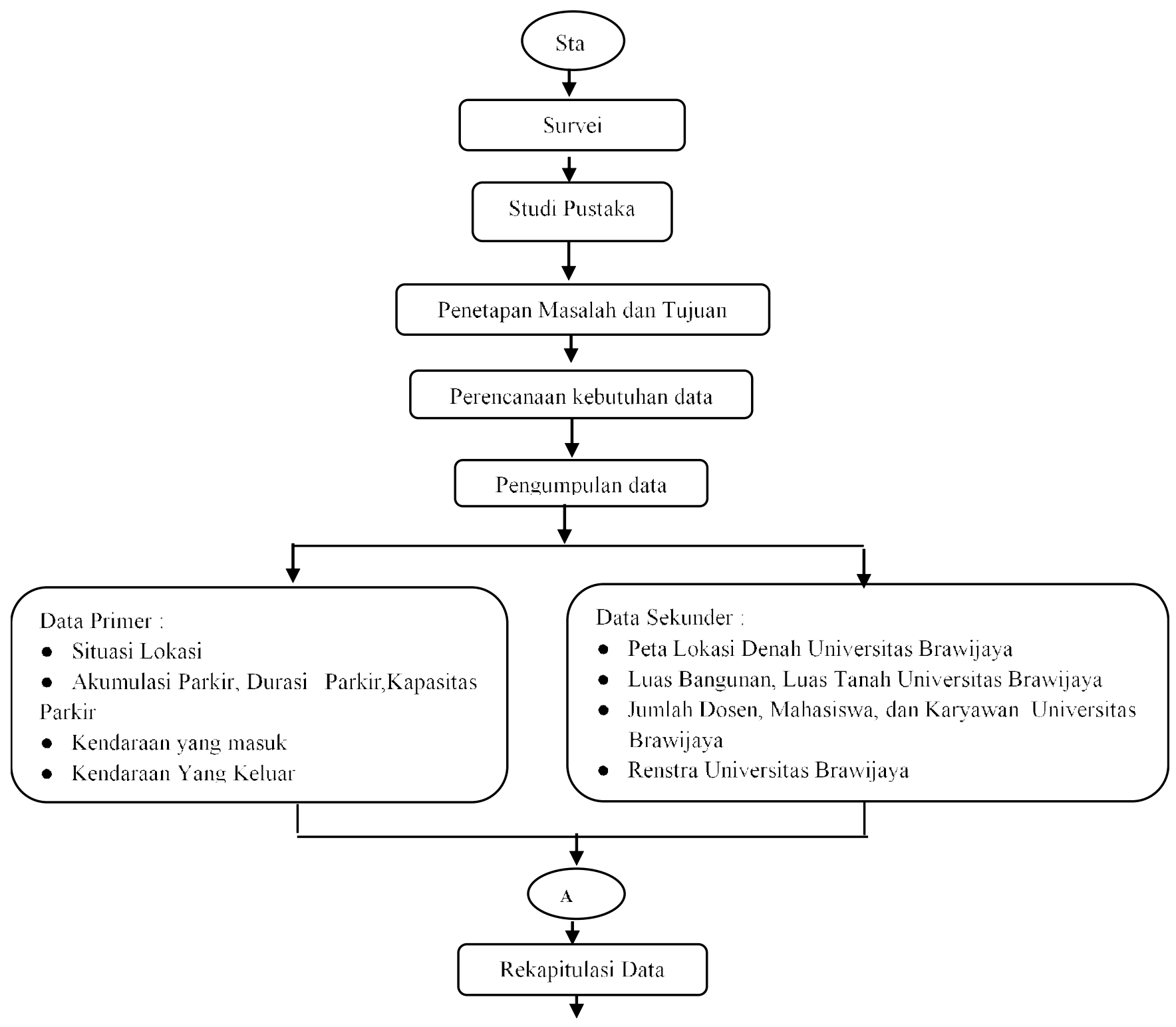




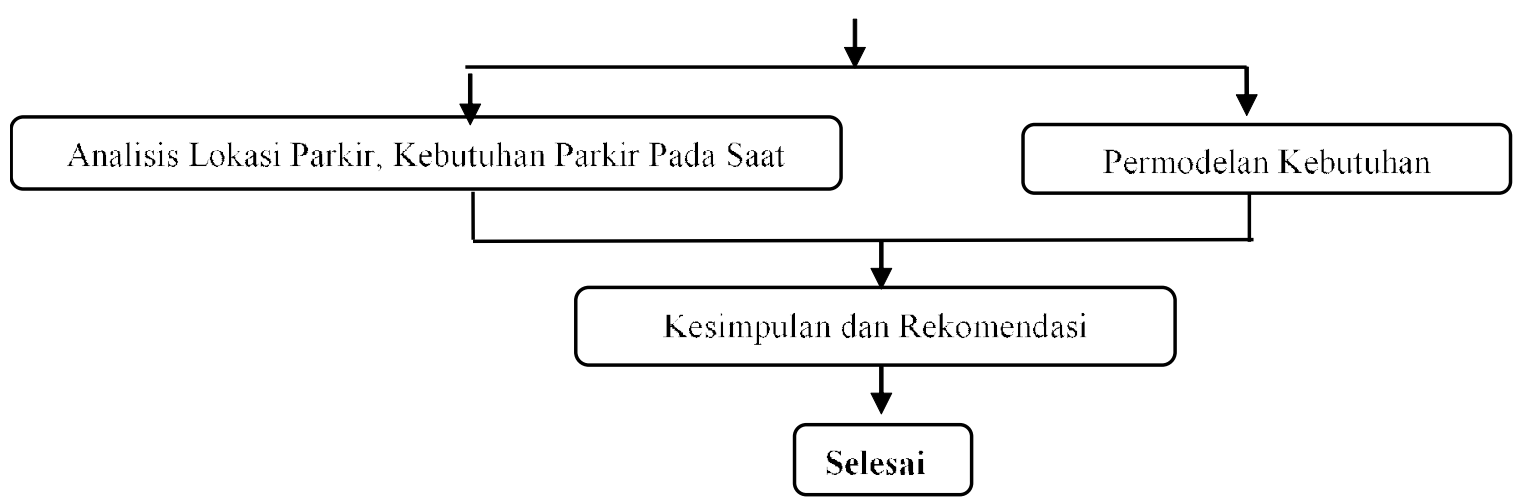

Gambar 1. Diagram alir penelitian

HASIL DAN PEMBAHASAN

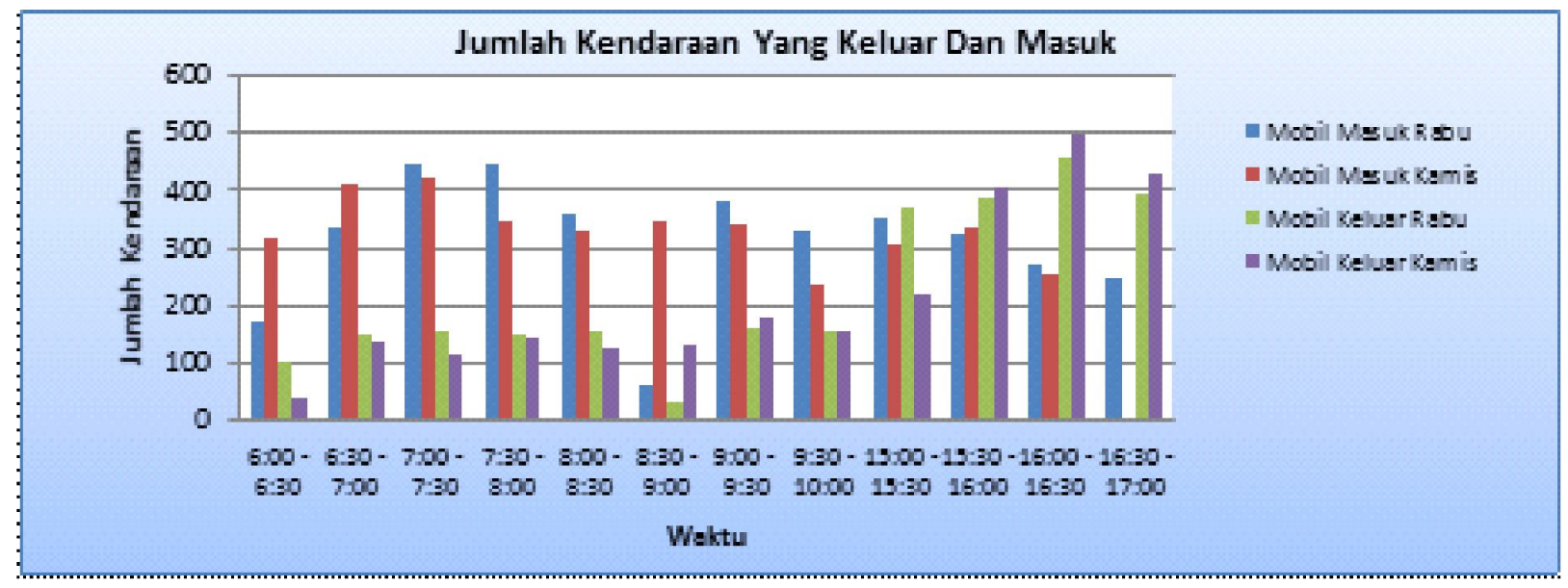

Gambar 2. Jumlah Mobil Yang Masuk dan Keluar

Dari grafik di atas dapat dilihat bahwa dari dua hari hasil pengamatan di lapangan yaitu pada hari Rabu dan hari Kamis terlihat bahwa jumlah mobil yang masuk maksimal jatuh pada hari Rabu adalah
446 kendaraan pada pukul 07.00-07.30 WIB dan pada pukul 07.30-08.00 WIB. Jumlah mobil yang keluar maksimal jatuh pada hari Kamis adalah 496 kendaraan pada pukul 16.00-16.30 WIB.

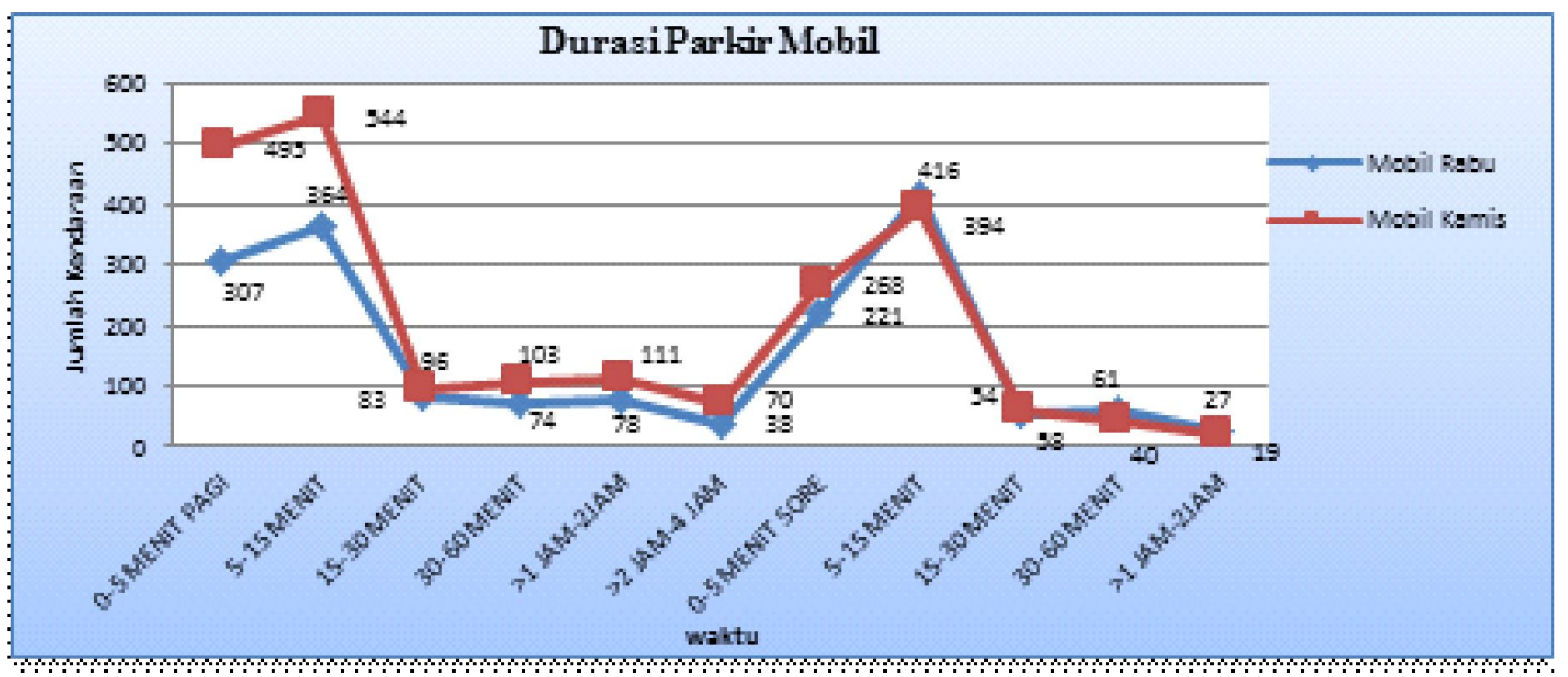

Gambar 3. Durasi Parkir Mobil

Dari gambar di atas dapat dilihat bahwa pada hari Kamis sore adalah durasi peak dari dua hari hasil pengamatan dimana jumlah mobil yang parkir dengan durasi 5-15 menit sebesar 544 kendaraan. 


\section{Analisis Parkir Sepeda Motor}

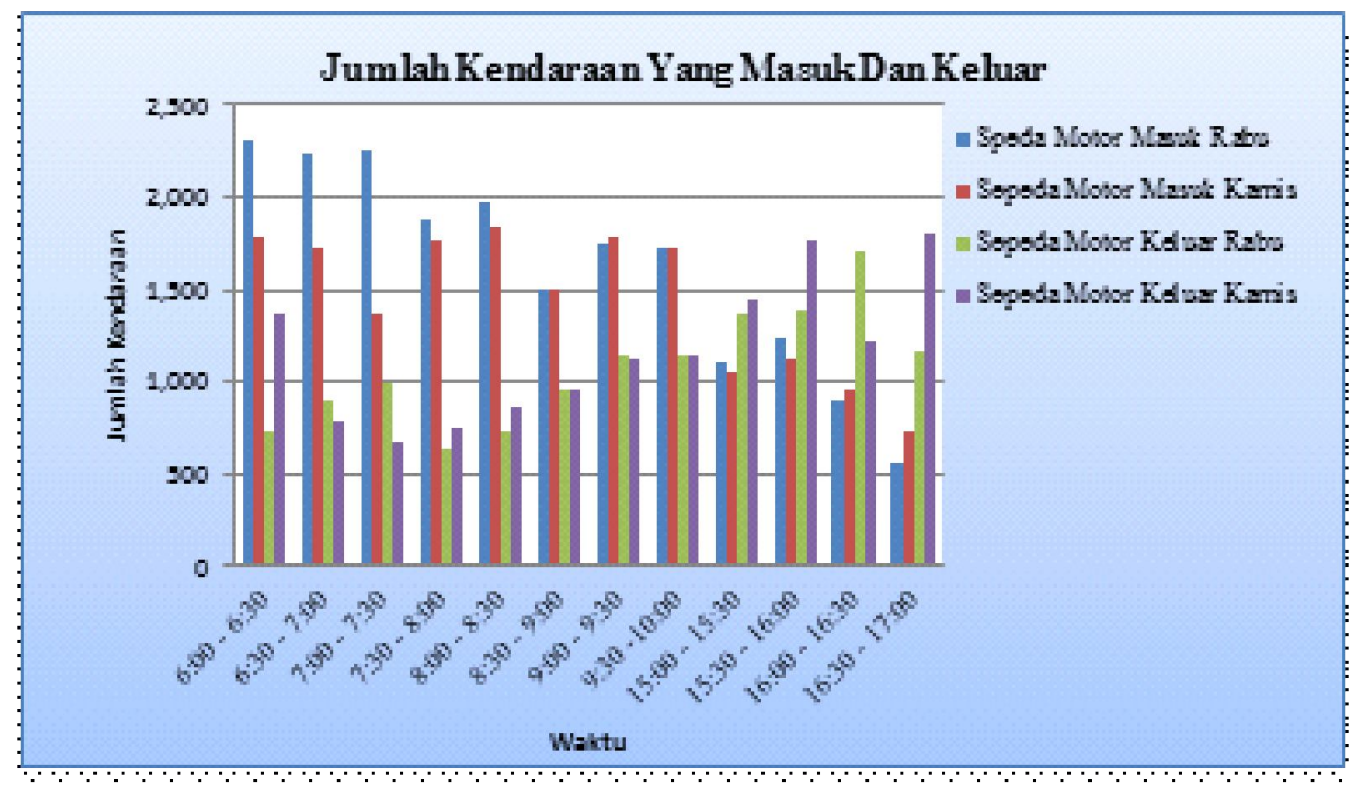

Gambar 4. Jumlah Sepeda Motor Yang Masuk dan Keluar

Dari grafik di atas dapat dilihat bahwa dari dua hari hasil pengamatan di lapangan yaitu pada hari Rabu dan hari Kamis terlihat jelas bahwa jumlah sepeda motor yang masuk maksimal dari kedua hari tersebut jatuh pada hari Rabu adalah 2.305 kendaraan pada pukul 06.00-06.30 WIB.Jumlah sepeda motor yang keluar maksimal jatuh pada hari Rabu sebesar 1.717 kendaraan pada pukul 16.0016.30 WIB.

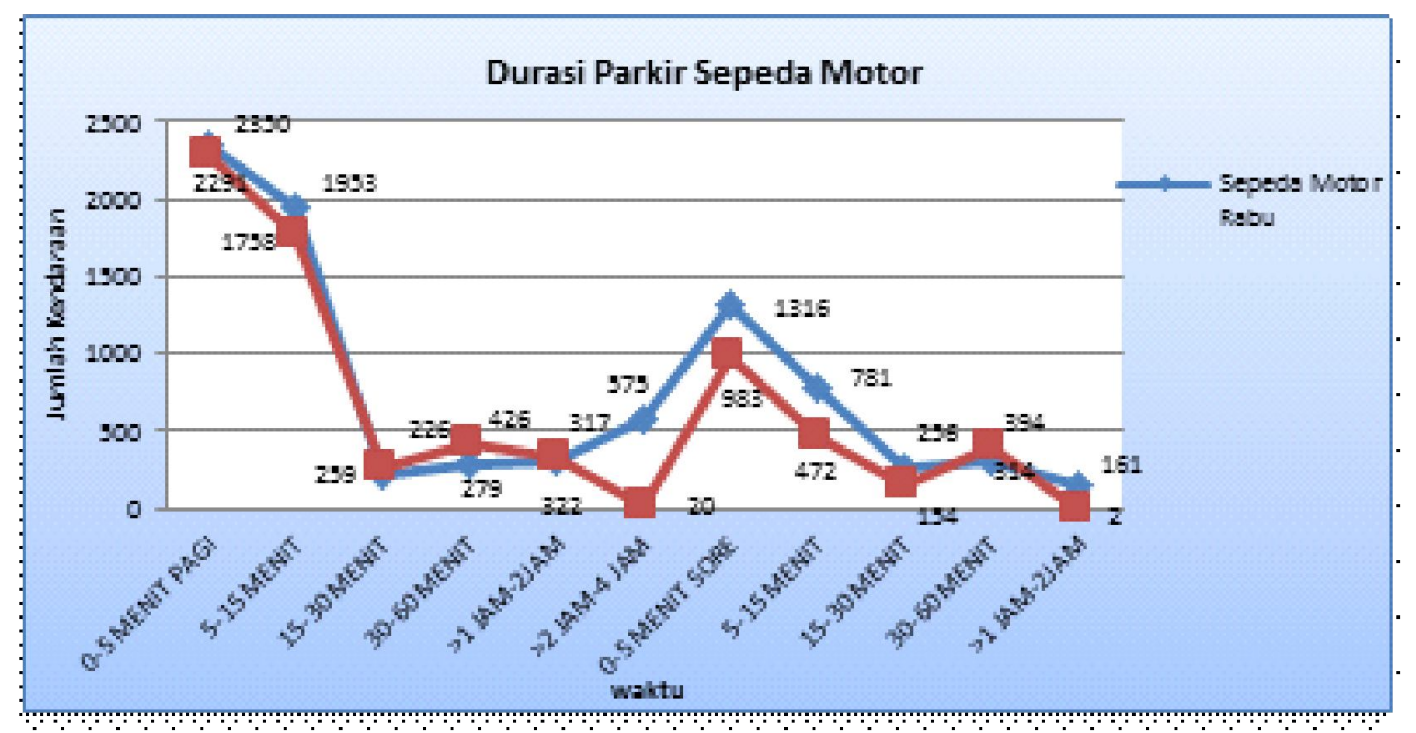

Gambar 5. Durasi Parkir Sepeda Motor

Dari gambar di atas dapat dilihat bahwa pada hari Rabu pagi adalah durasi peak dari dua hari hasil pengamatan dimana jumlah sepeda motor yang parkir dengan durasi 0-5 menit sebesar 2.350 kendaraan.

\section{Kebutuhan Ruang Parkir}

Pada tabel 1 di bawah ini memperlihatkan jumlah satuan ruang kebutuhan parkir dengan luasan yang ada. 
Tabel 1. Eksisting Satuan Ruang Kebutuhan Parkir

\begin{tabular}{|c|c|c|c|c|c|}
\hline No & Wilayah & $\begin{array}{l}\text { SRP } \\
\text { Sepeda } \\
\text { Motor }\end{array}$ & $\begin{array}{l}\text { SRP } \\
\text { Mobil }\end{array}$ & $\begin{array}{l}\text { Luasan } \\
\text { Parkiran Motor } \\
\left(\mathrm{m}^{2}\right)\end{array}$ & $\begin{array}{l}\text { Luasan } \\
\text { Parkiran } \\
\text { Mobil }\left(\mathrm{m}^{2}\right)\end{array}$ \\
\hline 1 & $\begin{array}{l}\text { Fakultas Ilmu Sosial dan Ilmu } \\
\text { Politik }\end{array}$ & 412 & 38 & 618 & 475 \\
\hline 2 & Fakultas MIPA & 375 & 54 & 562,5 & 675 \\
\hline 3 & Program Kedokteran Hewan & 170 & 18 & 255 & 225 \\
\hline 4 & Fakultas Pertanian & 482 & 56 & 723 & 700 \\
\hline 5 & $\begin{array}{l}\text { Fakultas Perikanan dan Ilmu } \\
\text { Kelautan }\end{array}$ & 445 & 47 & 667,5 & 587,5 \\
\hline 6 & Fakultas Peternakan & 289 & 32 & 433,5 & 400 \\
\hline 7 & Fakultas Kedokteran & 632 & 92 & 948 & 1150 \\
\hline 8 & $\begin{array}{l}\text { Fakultas Teknologi Informasi } \\
\text { dan Ilmu Komputer }\end{array}$ & 315 & 28 & 472,5 & 350 \\
\hline 9 & Fakultas Ilmu Budaya & 340 & 40 & 510 & 500 \\
\hline 10 & Fakultas Teknologi Pertanian & 389 & 44 & 583,5 & 550 \\
\hline 11 & Fakultas Hukum & 321 & 36 & 481,5 & 450 \\
\hline 12 & Fakultas Ekonomi dan Bisnis & 520 & 60 & 780 & 750 \\
\hline 13 & Fakultas Ilmu Administrasi & 572 & 52 & 858 & 650 \\
\hline 14 & Fakultas Teknik & 640 & 96 & 960 & 1200 \\
\hline & TOTAL & 5.902 & 693 & 8.853 & $8.662,5$ \\
\hline
\end{tabular}

\section{Kapasitas Parkir}

Kapasitas ruang parkir baik kendaraan roda 2 (dua) maupun kendaraan roda 4 (empat) yang ada di UB.

Tabel 2 Kapasitas Parkir Sepeda Motor dan Mobil

\begin{tabular}{cc}
\hline $\begin{array}{c}\text { Kapasitas Parkir } \\
\text { Sepeda Motor } \\
\text { (SRP) }\end{array}$ & $\begin{array}{c}\text { Kapasitas } \\
\text { Parkir Mobil } \\
\text { (SRP) }\end{array}$ \\
\hline 5.312 & 624 \\
\hline
\end{tabular}

Sumber: Hasil Analisis

\section{Analisis Model Regresi}

Dalam menentukan model regresi variable yang digunakan adalah :jumlah karyawan, jumlah mahasiswa, dan jumlah dosen. Oleh Karena itu model regresi yang ditetapkan, adalah dimana variabel :
$\mathrm{X}_{1}$ : jumlah karyawan

$\mathrm{X}_{2}$ : jumlah mahasiswa

$\mathrm{X}_{3}$ : jumlah dosen

$\mathrm{Y}_{1}$ : SRP Motor

$\mathrm{Y}_{2}:$ SRP Mobil

\section{Uji Korelasi Dengan Matriks Korelasi Untuk Sepeda Motor}

Sebelum variabel digunakan dalam penentuan model, terlebih dahulu harus dilakukan pengujian. Pengujian dilakukan untuk mengetahui seberapa besar pengaruh suatu variabel terhadap variabel yang lain. Penentuan variabel dilakukan bila antar variabel penjelas $(\mathrm{X})$ menunjukkan pengaruh hubungan yang lemah yaitu $\mathrm{R}^{2}<0,5$ dan hubungan variabel penjelas $(\mathrm{X})$ dengan variabel respon $(\mathrm{Y})$ menunjukkan hubungan yang kuat yaitu $R^{2}>0,5$. Hasil penilaian korelasi antar variable dapat dilihat pada output yang dihasilkan dari pengolahan data.

Tabel 3. Koefisien Korelasi Variabel Jumlah Karyawan, Mahasiswa, dan Dosen

\begin{tabular}{ccrrrr}
\hline & \multicolumn{5}{c}{ Correlations } \\
& \multicolumn{1}{c}{ Motor } & karyawan & mahasiswa & \multicolumn{1}{c}{ dosen } \\
\hline Pearson & motor & 1.000 & .838 & .883 & .850 \\
Correlatio & karyawan & .838 & 1.000 & .519 & .887 \\
$\mathrm{n}$ & mahasiswa & .883 & .519 & 1.000 & .552 \\
& dosen & .850 & .887 & .552 & 1.000 \\
\hline
\end{tabular}




\begin{tabular}{lcrrrr}
\hline Sig. (1- & motor &. & .000 & .000 & .000 \\
tailed) & karyawan & .000 &. & .029 & .000 \\
& mahasiswa & .000 & .029 &. & .020 \\
& dosen & .000 & .000 & .020 &. \\
$\mathrm{~N}$ & motor & 14 & 14 & 14 & 14 \\
& karyawan & 14 & 14 & 14 & 14 \\
& mahasiswa & 14 & 14 & 14 & 14 \\
& dosen & 14 & 14 & 14 & 14 \\
\hline
\end{tabular}

Sumber: Pengolahan Data

Dari model regresi yang dihasilkan tersebut perlu dilakukan uji korelasi antara sesama peubah bebas dan antara peubah bebas dengan peubah tidak bebas agar dapat memenuhi persyaratan statistik yaitu sesama peubah bebas tidak boleh mempunyai korelasi sedangkan antara peubah bebas dan peubah tidak bebas harus mempunyai korelasi.

\section{Metode Analisis Langkah Demi Langkah}

Dalam melakukan metode analisis langkah demi langkah yaitu untuk melihat hubungan antar variabel bebas yang memiliki pengaruh yang kuat terhadap variabel bebas lainya. Berdasarkan persyaratan yang ada antara sesama peubah bebas mempunyai korelasi dimana $\mathrm{R}<0.5$, sedangkan antara peubah bebas dan peubah tidak bebas harus mempunyai korelasi $\mathrm{R}^{2}>0.5$. Hasil korelasi antara variable dapat dilihat pada Tabel 4

\begin{tabular}{ccccc}
\multicolumn{5}{c}{ Tabel 4. Matriks Korelasi } \\
\hline \multicolumn{5}{c}{ Matrix Correlations } \\
\hline Y & 1 & $\mathbf{X 1}$ & $\mathbf{X 2}$ & $\mathbf{X 3}$ \\
$\mathrm{X} 1$ & 0.838 & 1 & - & - \\
$\mathrm{X} 2$ & 0.883 & 0.519 & 1 & - \\
$\mathrm{X} 3$ & 0.850 & 0.887 & 0.552 & 1 \\
\hline \multicolumn{5}{c}{ Sumber: Hasil Analisis }
\end{tabular}

Tabel 5 Pengaruh Hubungan Variabel Respon Dengan Variabel Penjelas

\begin{tabular}{cccc}
\hline No & Variabel & $\mathrm{r}$ & Keterangan \\
\hline 1 & $\mathrm{Ydan}_{1}$ & 0,838 & Hubungan kuat \\
2 & $\mathrm{Y}$ dan $\mathrm{X}_{2}$ & 0,883 & Hubungan kuat \\
3 & ${\mathrm{Y} \mathrm{dan} \mathrm{X}_{3}}^{0,850}$ & Hubungan kuat \\
\hline
\end{tabular}

Sumber: Hasil Analisis

Tabel 6. Pengaruh hubungan antar variabel penjelas

\begin{tabular}{cccc}
\hline No & Variabel & $\mathrm{r}$ & Keterangan \\
\hline 1 & $\mathrm{X}_{1}$ dan $\mathrm{X}_{2}$ & 0,519 & Hubungan kuat \\
\hline
\end{tabular}

\begin{tabular}{llll}
\hline 2 & $X_{1}$ dan $X_{3}$ & 0,887 & Hubungan kuat \\
\hline 3 & $X_{2}$ dan $X_{3}$ & 0,552 & Hubungan kuat \\
\hline
\end{tabular}

Sumber: Hasil Analisis

Dari analisa tabel tersebut terlihat bahwa faktor paling berpengaruh terletak pada variable $\mathrm{X}_{3}$ dimana antara lain:

- Pada korelasi $\mathrm{X}_{1}$ dan $\mathrm{X}_{2}$ mempunyai koefisien korelasi sebesar 0,519 ini berarti bahwa $\mathrm{X}_{2}$ mempunyai korelasi yang cukup tinggi terhadap $\mathrm{X}_{1}$. Menurut persyaratan yang ada maka hanya dipakai salah satu variable yaitu $X_{2}$ karena memiliki nilai korelasi yang lebih tinggi terhadap Y daripada $\mathrm{X}_{1}$

- $\quad$ Pada korelasi $\mathrm{X}_{1}$ dan $\mathrm{X}_{3}$ mempunyai koefisien korelasi sebesar 0,887 sedangkan pada nilai korelasi yang ada $\mathrm{X}_{3}$ lebih tinggi dari $\mathrm{X}_{1}$ sehingga menurut persyaratan yang ada maka hanya dipakai salah satu variable yaitu $\mathrm{X}_{3}$ karenamemiliki nilai korelasi yang lebih tinggi terhadap Y daripada $\mathrm{X}_{1}$.

- $\quad$ Pada korelasi antara $X_{2}$ dan $X_{3}$ mempunyai koefisien korelasi $=0,552$ dan nilai korelasi $X_{2}$ lebih tinggi dari $X_{3}$ sehingga dipakai $X_{2}$, sehingga menurut persyaratan yang ada maka hanya dipakai salah satu variable yaitu $\mathrm{X}_{2}$ karenamemiliki nilai korelasi yang lebih tinggi terhadap $\mathrm{Y}$ daripada $\mathrm{X}_{3}$.

Dari hasil tersebut terlihat bahwa Variabel $X_{2}$ nilai korelasinya lebih tinggi terhadap $\mathrm{Y}$ daripada variabel-variabel lain. Dengan menghilangkan variabel $X_{1}$, $d a n X_{3}$ yaitu variabel jumlah dosen dan jumlah karyawan didapatkan model dari analisa regresi linier berganda adalah : $\mathbf{Y}_{\mathbf{1}}=\mathbf{1 3 2 , 4 3 7}+$ $0.068 \mathrm{X}_{2}$

Model regresi yang diusulkan adalah model di atasyang memiliki nilai $\mathrm{R}^{2} 0.780 \mathrm{Y}_{1}=132,437+0.068$ $\mathrm{X}_{2}$ menunjukkan bahwa setiap kenaikan satu satuan 
atas variabel $\mathrm{X}_{2}$, akan mempengaruhi Ysebesar 0,068 Koefisien determinasi yang dihasilkan menunjukkan nilai 0,068 . Hal ini berarti variabel jumlah mahasiswa berpengaruh kuat secara positif sebesar $78 \%$ terhadap SRP Motor, sedangkan sisanya sebesar $22 \%$ dipengaruhi oleh faktor yang lain.

\section{Uji Korelasi Dengan Matriks Korelasi Untuk Mobil}

Seperti pada uji korelasi untuk sepeda motor pada kendaraan roda empat (mobil) pun dilakukan seperti itu

Tabel 7. Koefisien Korelasi Variabel Jumlah Karyawan, Mahasiswa, dan Dosen

\begin{tabular}{ccrrrr}
\hline \multicolumn{5}{c}{ Correlations } \\
\hline Pearson & mobil & mahasiswa & dosen & karyawan \\
\hline Correlation & 1.000 & .640 & .976 & .924 \\
& mahasiswa & .640 & 1.000 & .552 & .519 \\
& dosen & .976 & .552 & 1.000 & .887 \\
Sig. (1-tailed) & karyawan & .924 & .519 & .887 & 1.000 \\
& mobil &. & .007 & .000 & .000 \\
& mahasiswa & .007 &. & .020 & .029 \\
& dosen & .000 & .020 &. & .000 \\
& karyawan & .000 & .029 & .000 &. \\
& mobil & 14 & 14 & 14 & 14 \\
& mahasiswa & 14 & 14 & 14 & 14 \\
& dosen & 14 & 14 & 14 & 14 \\
& karyawan & 14 & 14 & 14 & 14 \\
\hline
\end{tabular}

Sumber: Pengolahan Data

Tabel 8. Matriks korelasi

\begin{tabular}{ccccc}
\hline & \multicolumn{4}{c}{ Matrix Correlations } \\
\cline { 2 - 5 } & $\mathbf{Y}$ & $\mathbf{X 1}$ & $\mathbf{X 2}$ & $\mathbf{X 3}$ \\
\hline $\mathrm{Y}$ & 1 & - & - & - \\
$\mathrm{X} 1$ & 0.924 & 1 & - & - \\
$\mathrm{X} 2$ & 0.640 & 0.519 & 1 & - \\
$\mathrm{X} 3$ & 0.976 & 0.887 & 0.552 & 1 \\
\hline \multicolumn{5}{c}{ Sumber: Hasil Analisis }
\end{tabular}

Tabel 9. Pengaruh hubungan variabel respon dengan variabel penjelas

\begin{tabular}{cccc}
\hline No & Variabel & r & Keterangan \\
\hline 1 & Y dan $X_{1}$ & 0,924 & Hubungan kuat \\
2 & Y dan $X_{2}$ & 0,640 & Hubungan kuat \\
3 & ${\text { Y dan } X_{3}}_{2}$ & 0,976 & Hubungan kuat \\
\hline
\end{tabular}

Sumber: Hasil Analisis

Tabel 10 Pengaruh hubungan antar variabel penjelas

\begin{tabular}{cccc}
\hline No & Variabel & $\mathrm{r}$ & Keterangan \\
\hline 1 & $\mathrm{X}_{1}$ dan $\mathrm{X}_{2}$ & 0,519 & Hubungan kuat \\
2 & $\mathrm{X}_{1}$ dan $\mathrm{X}_{3}$ & 0,887 & Hubungan kuat \\
3 & $\mathrm{X}_{2}$ dan $\mathrm{X}_{3}$ & 0,552 & Hubungan kuat \\
\hline
\end{tabular}

Sumber: Hasil Analisis
Hasil yang didapatkan dari masing-masing hubungan dapat dilihat pada lampiran yang ada.Dari analisa tabel tersebut terlihat bahwa faktor paling berpengaruh terletak pada variable $\mathrm{X}_{3}$ dimana antara lain:

- $\quad$ Pada korelasi $X_{1}$ dan $X_{2}$ mempunyai koefisien korelasi $=0.519$ ini berarti bahwa $X_{l}$ mempunyai korelasi yang cukup tinggi terhadap $X_{2}$. Menurut persyaratan yang ada maka hanya dipakai salah satu variable yaitu $X_{1}$ karenamemiliki nilai korelasi yang lebih tinggi terhadap Y daripada $\mathrm{X}_{2}$

- $\quad$ Pada korelasi $X_{1}$ dan $X_{3}$ mempunyai koefisien korelasi $=0.887$ sedangkan pada nilai korelasi yang ada $X_{3}$ lebih tinggi dari $X_{1}$ sehingga menurut persyaratan yang ada maka hanya dipakai salah satu variable yaitu $\mathrm{X}_{3}$ karenamemiliki nilai korelasi yang lebih tinggi terhadap Y daripada $\mathrm{X}_{1}$

- $\quad$ Pada korelasi antara $X_{2}$ dan $X_{3}$ mempunyai koefisien korelasi $=0.552$ dan nilai korelasi $X_{3}$ lebih tinggi dari $X_{2}$ sehingga menurut persyaratan yang ada maka hanya dipakai salah satu variable yaitu $X_{3}$ karenamemiliki nilai 
korelasi yang lebih tinggi terhadap Y daripada $\mathrm{X}_{2}$

Dari hasil tersebut terlihat bahwa Variabel $X_{3}$ nilai korelasinya lebih tinggi terhadap $\mathrm{Y}$ daripada variabel-variabel lain. Dengan menghilangkan variabel $X_{1}$, ,an $X_{2}$, yaitu variabel jumlah karyawan dan jumlah mahasiswa didapatkan model dari analisa regresi linier berganda adalah: $Y_{2}=\mathbf{1 7 , 1 4 9}+\mathbf{0 . 2 4 9}$ $\mathbf{X}_{3}$

Model regresi yang diusulkan adalah model di atasyang memiliki nilai $\mathrm{R}^{2} 0.952 \mathrm{Y}_{2}=17,149+0.249$ $\mathrm{X}_{3}$ menunjukkan bahwa setiap kenaikan satu satuan atas variabel $\mathrm{X}_{2}$, akan mempengaruhi Ysebesar 0,249 Koefisien determinasi yang dihasilkan menunjukkan nilai 0,952 . Hal ini berarti variabel jumlah mahasiswa berpengaruh kuat secara positif sebesar 95,2.\% terhadap SRP Mobil, sedangkan sisanya sebesar $4,8 \%$ dipengaruhi oleh faktor yang lain.

Peramalan Pertambahan Jumlah Karyawan, Mahasiswa, dan Dosen Universitas Brawijaya

Laju pertumbuhan penduduk adalah perubahan jumlah penduduk di suatu wilayah tertentu pada waktu tertentu. Rumus laju pertumbuhan penduduk adalah sebagai berikut.

$$
P_{t}=P_{o}(1+r)^{2}
$$

atau
$r=\left(\frac{P_{t}}{P_{o}}\right)^{\frac{1}{t}}-1$

\section{Keterangan:}

$P t=$ jumlah penduduk pada tahun $t$

$P o=$ jumlah penduduk pada tahun dasar

$t=$ jangka waktu

$r=$ laju pertumbuhan penduduk

Dari rumus perhitungan di atas dapat dihasilkan bahwa pertumbuhan jumlah mahasiswa tiap tahunnya sebesar $8 \%$, pertumbuhan jumlah dosen sebesar $5,1 \%$, dan pertumbuhan jumlah karyawan sebesar $12 \%$.

Tabel 11. Kebutuhan Ruang Parkir Kondisi Eksisting

\begin{tabular}{cccc}
\hline No & Kendaraan & $\begin{array}{c}\text { SRP } \\
\text { Kendaraan }\end{array}$ & Luas Lahan $\left(\mathrm{m}^{2}\right)$ \\
\hline 1 & Sepeda & 5.902 & 8.853 \\
& Motor & & $8.662,5$ \\
2 & Mobil & 693 &
\end{tabular}

Tabel 12 Prediksi Kebutuhan Ruang Parkir 5 Tahun Mendatang

\begin{tabular}{cccc}
\hline No & Kendaraan & $\begin{array}{c}\text { SRP } \\
\text { Kendaraan }\end{array}$ & $\begin{array}{c}\text { Luas Lahan } \\
\left(\mathrm{m}^{2}\right)\end{array}$ \\
\hline 1 & $\begin{array}{c}\text { Sepeda } \\
\text { Motor }\end{array}$ & 6.167 & $9.250,5$ \\
2 & Mobil & 698 & 8.725 \\
\hline
\end{tabular}

Sumber: Hasil Analisis

\section{Alternatif penyediaan gedung parkir}

Tabel 13. Prediksi SRP 5 Tahun Mendatang Pada Setiap Fakultas

\begin{tabular}{|c|c|c|c|c|c|c|c|c|c|}
\hline No & Fakultas & $\begin{array}{l}\text { SRP } \\
\text { Sepeda } \\
\text { Motor } \\
\text { Eksisting }\end{array}$ & $\begin{array}{l}\text { Prediksi } \\
\text { SRP } \\
\text { Sepeda } \\
\text { Motor 5 } \\
\text { Tahun } \\
\text { Yang } \\
\text { Akan } \\
\text { Datang }\end{array}$ & $\begin{array}{l}\text { SRP } \\
\text { Mobil } \\
\text { Eksisting }\end{array}$ & $\begin{array}{l}\text { Prediksi } \\
\text { SRP } \\
\text { Mobil } 5 \\
\text { Tahun } \\
\text { Yang } \\
\text { Akan } \\
\text { Datang }\end{array}$ & $\begin{array}{c}\text { SRP } \\
\text { Sepeda } \\
\text { Motor } \\
\text { Yang } \\
\text { Dibutuhkan } \\
5 \text { Tahun } \\
\text { Akan } \\
\text { Datang }\end{array}$ & $\begin{array}{l}\text { SRP Mobil } \\
\text { Yang } \\
\text { Dibutuhkan } \\
5 \text { Tahun } \\
\text { Akan } \\
\text { Datang }\end{array}$ & $\begin{array}{c}\text { Luas } \\
\text { ParkirSepeda } \\
\text { Motor Yang } \\
\text { Dibutuhkan } \\
5 \text { Tahun } \\
\text { Akan Datang } \\
\left(\mathrm{m}^{2}\right)\end{array}$ & $\begin{array}{c}\text { Luas } \\
\text { SParkir } \\
\text { Mobil } \\
\text { Yang } \\
\text { Dibutuhkan } \\
5 \text { Tahun } \\
\text { Akan } \\
\text { Datang } \\
\left(\mathrm{m}^{2}\right)\end{array}$ \\
\hline 1 & $\begin{array}{l}\text { Fakultas } \\
\text { Ilmu Sosial } \\
\text { dan Ilmu } \\
\text { Politik }\end{array}$ & 412 & 601 & 38 & 40 & 189 & 2 & 283,5 & 25 \\
\hline 2 & $\begin{array}{l}\text { Fakultas } \\
\text { MIPA }\end{array}$ & 375 & 405 & 54 & 60 & 30 & 6 & 45 & 75 \\
\hline 3 & $\begin{array}{l}\text { Program } \\
\text { Kedokteran } \\
\text { Hewan }\end{array}$ & 170 & 189 & 18 & 20 & 19 & 2 & 28,5 & 25 \\
\hline
\end{tabular}




\begin{tabular}{|c|c|c|c|c|c|c|c|c|c|}
\hline 4 & $\begin{array}{l}\text { Fakultas } \\
\text { Pertanian }\end{array}$ & 482 & 518 & 56 & 58 & 36 & 2 & 54 & 25 \\
\hline 5 & $\begin{array}{l}\text { Fakultas } \\
\text { Perikanan } \\
\text { dan Ilmu } \\
\text { Kelautan }\end{array}$ & 445 & 543 & 47 & 50 & 98 & 3 & 147 & 37,5 \\
\hline 6 & $\begin{array}{l}\text { Fakultas } \\
\text { Peternakan }\end{array}$ & 289 & 445 & 32 & 36 & 156 & 4 & 234 & 50 \\
\hline 7 & $\begin{array}{l}\text { Fakultas } \\
\text { Kedokteran }\end{array}$ & 632 & 682 & 92 & 94 & 50 & 2 & 75 & 25 \\
\hline 8 & $\begin{array}{l}\text { Fakultas } \\
\text { Teknologi } \\
\text { Informasi } \\
\text { dan Ilmu } \\
\text { Komputer }\end{array}$ & 315 & 431 & 28 & 30 & 116 & 2 & 174 & 25 \\
\hline 9 & $\begin{array}{l}\text { Fakultas } \\
\text { Ilmu } \\
\text { Budaya }\end{array}$ & 340 & 647 & 40 & 42 & 307 & 2 & 460,5 & 25 \\
\hline 10 & $\begin{array}{l}\text { Fakultas } \\
\text { Teknologi } \\
\text { Pertanian }\end{array}$ & 389 & 466 & 44 & 45 & 77 & 1 & 115,5 & 12,5 \\
\hline 11 & $\begin{array}{l}\text { Fakultas } \\
\text { Hukum }\end{array}$ & 321 & 404 & 36 & 41 & 83 & 5 & 124,5 & 62,5 \\
\hline 12 & $\begin{array}{l}\text { Fakultas } \\
\text { Ekonomi } \\
\text { dan Bisnis }\end{array}$ & 520 & 660 & 60 & 62 & 140 & 2 & 210 & 25 \\
\hline 13 & $\begin{array}{l}\text { Fakultas } \\
\text { Ilmu } \\
\text { Administrasi }\end{array}$ & 572 & 665 & 52 & 53 & 93 & 1 & 139,5 & 12,5 \\
\hline \multirow[t]{2}{*}{14} & $\begin{array}{l}\text { Fakultas } \\
\text { Teknik }\end{array}$ & 640 & 651 & 96 & 97 & 11 & 1 & 16,5 & 12,5 \\
\hline & TOTAL & 5.902 & 7.307 & 693 & 728 & 1.405 & 35 & $2.107,5$ & 437,5 \\
\hline
\end{tabular}

Sumber: Hasil Analisis

Penempatan area gedung parkir baru diambil dengan asumsi berdasarkan lahan yang tersedia di UB dan area tersebut merupakan tempat yang strategis sehingga memberi kemudahan bagi mahasiswa, dosen, dan karyawan pada kawasan tersebut. Dari hasil perhitungan dengan luasan yang ada serta jumlah SRP yang ada maka diketahui bahwa untuk perencanaan gedung parkir baru yaitu

- Untuk kawasan 1 yang meliputi Fakultas Ilmu Sosial dan Ilmu Politik, Fakultas Teknik, Program Kedokteran Hewan, Fakultas Hukum memiliki luas lahan yaitu $453 \mathrm{~m}^{2}$ dengan perencanaan pembangunan alternatif gedung parkir yang terdiri dari 2 lantai. Dibawah ini adalah gambar salah satu area tempat parkir yang diusulkan.

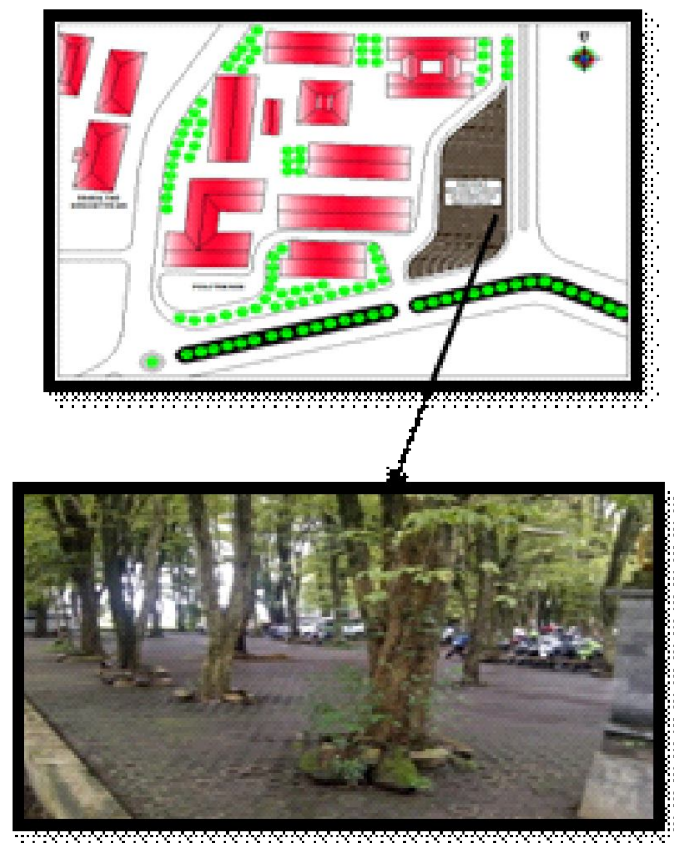

Gambar 6. RencanaLahan Area Gedung Parkir

$$
\text { Baru }
$$

- Untuk kawasan 2 yang meliputi Fakultas Ilmu Administrasi, Fakultas Ekonomi dan Bisnis 
memiliki luas lahan yaitu $349,5 \mathrm{~m}^{2}$ dengan perecanaan pembangunan alternatif gedung parkir yang terdiri dari 2 lantai. Dibawah ini adalah gambar salah satu area tempat parkir yang diusulkan.

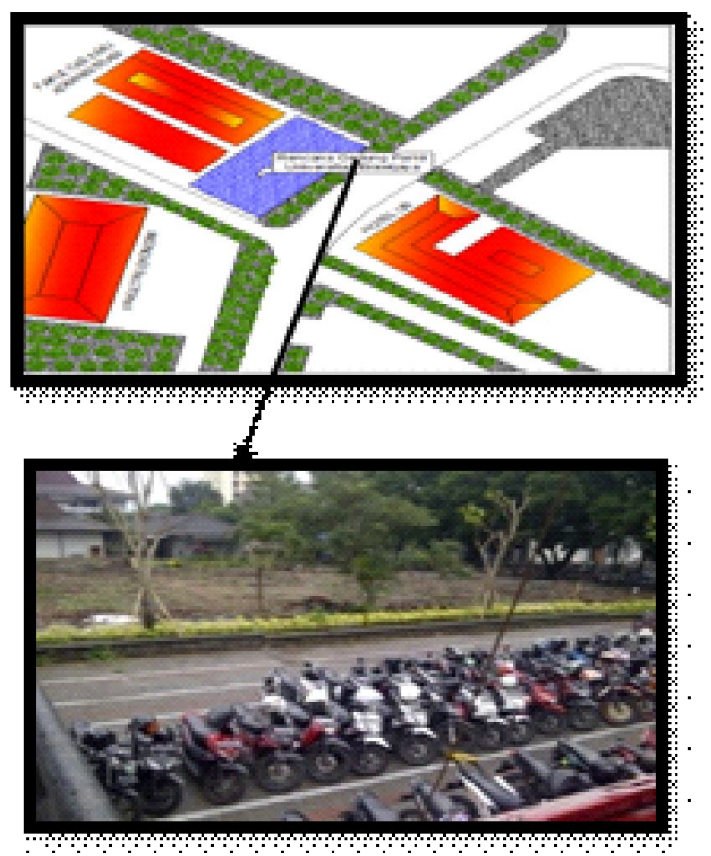

Gambar 7 RencanaLahan Area Gedung Parkir Baru

- Untuk kawasan 3 yang meliputi Fakultas Teknologi Pertanian, Fakultas Teknologi Informasi dan Ilmu Komputer, Fakultas Kedokteran memiliki luas lahan yaitu $364,5 \mathrm{~m}^{2}$ dengan perecanaan pembangunan alternatif gedung parkir yang terdiri dari 2 lantai.Dibawah ini adalah gambar salah satu area tempat parkir yang diusulkan.

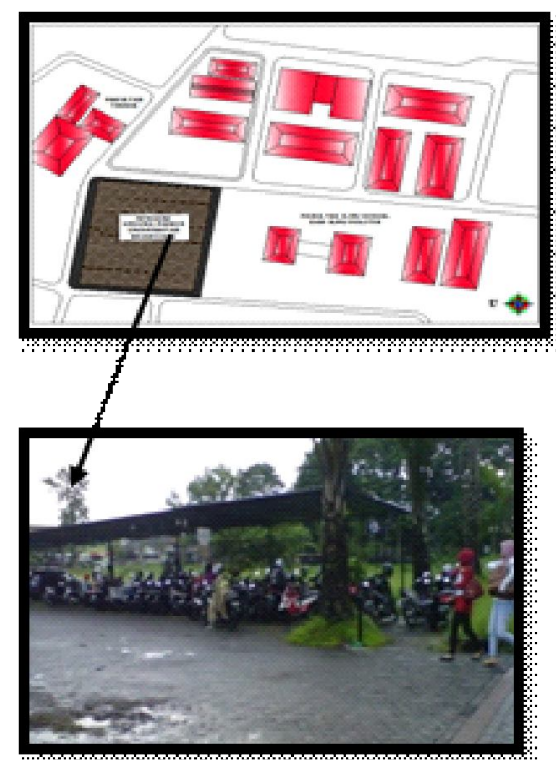

Gambar 8 Rencanalahan Area Gedung Parkir Baru
- Untuk kawasan 4 yang meliputi Fakultas MIPA, Fakultas Ilmu Budaya, Fakultas Peternakan memiliki luas lahan yaitu $739,5 \mathrm{~m}^{2}$ dengan perecanaan pembangunan alternatif gedung parkir yang terdiri dari 2 lantai Dibawah ini adalah gambar salah satu area tempat parkir yang diusulkan.

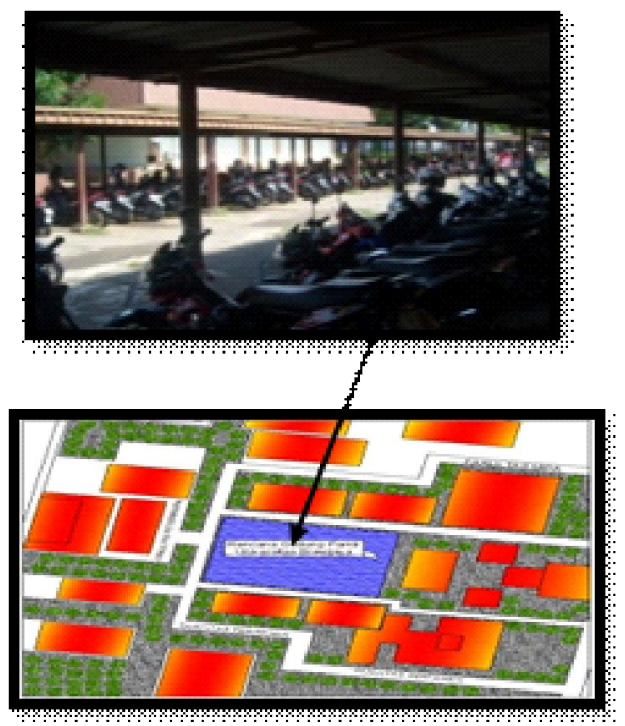

Gambar 9. RencanaLahan Area Gedung Parkir Baru

- Untuk kawasan 5 yang meliputi Fakultas Perikanan dan Ilmu Kelautan, Fakultas Pertanian memiliki luas lahan yaitu $201 \mathrm{~m}^{2}$ dengan perecanaan pembangunan alternatif gedung parkir yang terdiri dari 2 lantai. Dibawah ini adalah gambar salah satu area tempat parkir yang diusulkan.

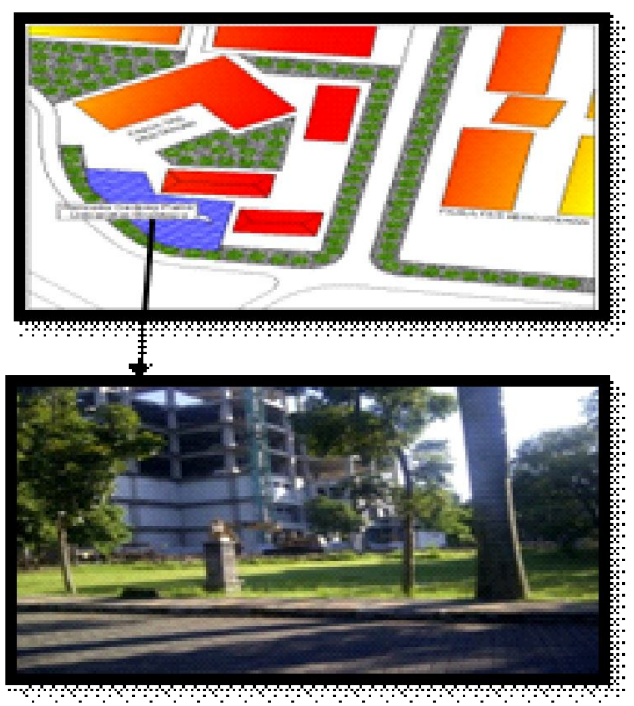

Gambar10 RencanaLahan Area Gedung Parkir Baru 


\section{KESIMPULAN DAN SARAN}

\section{Kesimpulan}

- Berdasarkan hasil analisa dan pembahasan maka dapat disimpulkan:

- Kapasitas parkir mobil yang ada di Kampus Universitas Brawijaya pada saat ini yaitu sebesar 624 SRP, sedangkan untuk kapasitas sepeda motor yaitu sebesar 5.312 SRP.

- Kebutuhan ruang parkir mobil pada saat ini di Universitas Brawijaya yaitu sebesar 693 SRP, dan untuk kebutuhan ruang parkir sepeda motor yaitu sebesar 5.902 SRP.

- Dari hasil analisis statistik untuk model kebutuhan parkir mobil didapatkan,

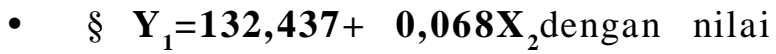
koefisien determinasi $\left(R^{2}\right)$ sebesar 0,78 . Hal ini berarti bahwa model regresi yang didapatkan mampu menjelaskan pengaruh antara variabel-variabel $\mathrm{X}$ terhadap $\mathrm{Y}$ sebesar $78 \%$. Sedangkan model kebutuhan parkir sepeda motor didapatkan, $\mathbf{Y}_{2}=\mathbf{1 7 , 1 4 9 +}$ $\mathbf{0 , 2 4 9} \mathrm{X}_{3}$ dengan nilai koefisien determinasi $\left(\mathrm{R}^{2}\right)$ sebesar 0,952. Hal ini berarti bahwa model regresi yang didapatkan mampu menjelaskan pengaruh antara variabelvariabel X terhadap Y sebesar 95,2\%.

- Rekomendasi guna memenuhi kebutuhan parkir untuk 5 tahun yang akan datang adalah dengan penyediaan alternatif gedung parkir di 5 kawasan dengan total SRP dan luas lahan yang ditunjukkan tabel di bawah ini:

Tabel 14. Rekomendasi Kebutuhan Parkir Untuk 5 Tahun Yang Akan Datang

\begin{tabular}{|c|c|c|c|c|c|}
\hline $\begin{array}{l}\text { Kawasan } \\
\text { atau } \\
\text { Wilayah }\end{array}$ & Fakultas & $\begin{array}{l}\text { Total SRP } \\
\text { Sepeda } \\
\text { Motor Untuk } \\
\text { Kebutuhan } 5 \\
\text { Tahun Yang } \\
\text { Akan } \\
\text { Datang }\end{array}$ & $\begin{array}{l}\text { Total SRP } \\
\text { Mobil } \\
\text { Untuk } \\
\text { Kebutuhan } \\
5 \text { Tahun } \\
\text { Yang Akan } \\
\text { Datang }\end{array}$ & $\begin{array}{l}\text { Total Luas } \\
\text { Parkir Sepeda } \\
\text { Motor Untuk } \\
\text { Kebutuhan } 5 \\
\text { Tahun Yang } \\
\text { Akan Datang } \\
\left(\mathrm{m}^{2}\right)\end{array}$ & $\begin{array}{l}\text { Total Luas } \\
\text { Parkir Mobil } \\
\text { Untuk } \\
\text { Kebutuhan } 5 \\
\text { Tahun Yang } \\
\text { Akan Datang } \\
\left(\mathrm{m}^{2}\right)\end{array}$ \\
\hline 1 & $\begin{array}{l}\text { Fakultas Ilmu Sosial dan Ilmu } \\
\text { Politik, Fakultas Teknik, } \\
\text { Program Kedokteran Hewan, } \\
\text { Fakultas Hukum }\end{array}$ & 302 & 10 & 453 & 125 \\
\hline 2 & $\begin{array}{l}\text { Fakultas Ilmu Administrasi, } \\
\text { Fakultas Ekonomi dan Bisnis }\end{array}$ & 233 & 3 & 349,5 & 37,5 \\
\hline 3 & $\begin{array}{l}\text { Fakultas Teknologi Pertanian, } \\
\text { Fakultas Teknologi Informasi } \\
\text { dan Ilmu Komputer, Fakultas } \\
\text { Kedokteran }\end{array}$ & 243 & 5 & 364,5 & 62,5 \\
\hline 4 & $\begin{array}{l}\text { Fakultas MIPA, Fakultas Ilmu } \\
\text { Budaya, Fakultas Peternakan }\end{array}$ & 493 & 12 & 739,5 & 150 \\
\hline 5 & $\begin{array}{l}\text { Fakultas Perikanan dan Ilmu } \\
\text { Kelautan, Fakultas Pertanian }\end{array}$ & 134 & 5 & 201 & 62,5 \\
\hline
\end{tabular}

\section{Saran}

Berikut ini adalah beberapa saran yang disampaikan dalam upaya menanggulangi permasalahan parkir di Universitas Brawijaya, Malang adalah :

- $\quad$ Pengaturan parkir lebih di tingkatkan terutama pada jam-jam sibuk (peak hours), salah satunya dengan penambahan jumlah petugas yang mengawasi parkiran sehingga parkiran tertata dengan rapi tanpa adanya kendaraan parkir sembarangan yang dapat menghambat sirkulasi kendaraan yang lain.

- Adanya kebijakan dari pihak Kampus untuk pengurangan pemakaian kendaraan pribadi guna terciptanya suasana Kampus yang lebih sejuk, nyaman dan bebas dari polusi akibat 
banyaknya aktivitas dari kendaraan pribadi, sehingga akan terciptanya penataan parkir yang lebih rapi, aman, nyaman dan teratur.

- Perlu adanya kajian lebih lanjut tentang manajemen parkir pada penelitian berikutnya agar meningkatkan tingkat kenyamanan dosen, mahasiswa, serta karyawan.

\section{DAFTAR PUSTAKA}

Abubakar, I. dkk.1998. Pedoman Perencanaan Dan Pengoperasian Fasilitas Parkir. Direktorat Bina Sistem Lalu Lintas Angkutan Kota. Direktorat Jendral Perhubungan Darat, Jakarta.

Bernardino, Van der Hoofd. 2013. Parking Policy And Urban Mobility Level Of Service System Dynamics As ATool For Decision Making, European Journal of Transport and Infrastructure Research, 13(3), 2013, pp. 239258.

Dephub, 1996. Pedoman Teknis Penyelenggaraan Fasilitas Parkir, Direktur Jenderal Perhubungan Darat.

Pranoto. 2007. Model Kebutuhan Parkir Mobil Gedung Perkantoran Bank di Kota Malang. Teknologi dan Kejuruan, vol. 30, No, 2, 129140 . Universitas Negeri Malang, Malang.

Priyanto, S. dan Arliani, S.W. 2005. Penataan Ruang Parkir Badan Jalan Untuk Meningkatkan Kinerja Jalan. Simposium VIII FSTPT, Universitas Sriwijaya, Palembang.

Sagita , I Nyoman, 2011. Kajian Kelayakan Finansial Pembangunan Gedung Parkir Universitas Udayana Di Jalan Sudirman Denpasar. Tesis Teknik Sipil. Universitas Udayana, Denpasar.

Sudirahardjo, Ririh, 2004. Analisis Kebutuhan Ruang Parkir Di Pasar Bandarjo Ungaran. Tesis Teknik Sipil. Universitas Diponegoro, Semarang.

Sulistio, Harnen, dkk, 2007. Model Kebutuhan Parkir Pada Pusat Perbelanjaan Di Kota Malang Studi Kasus Plasa Dieng, Plasa Gajah Mada, Dan Malang Plasa. Jurnal Transportasi Vol. 7 No. 1 Juni 2001: 57-66

Suwardi.2007. Analisis Studi Karakteristik Parkir (Studi Kasus R.S. DR. Muwardi, Swalayan Matahari Purwosari, Kampus UMS di Surakarta). Jurnal Teknik Sipil Vol. 5 No. 1
ISSN 1693-4652. Universitas Muhammadiyah Surakarta, Surakarta.

Suwardi, 2008. Analisis Karakteristik Dan Dampak Parkir Terhadap LaluLintas, Di Solo Grand Mall Surakarta. Jurnal Teknik Sipil Volume 8 No.2, Februari 2008 : 105-118. Tamin, Ofyar Z, 2000, Perencanaan Dan Pemodelan Transportasi, ITB, Bandung 